\title{
MEDIA MASA SEBAGAI INSTRUMEN DIPLOMASI AMERIKA SERIKAT DALAM KASUS INVASI KE IRAK DAN AFGANISTAN
}

\author{
Dedy Permadi \\ Jurusan Ilmu Hubungan Internasional Universitas Gadjah Mada \\ Sekretaris Institute of International Studies Universitas Gadjah Mada
}

\begin{abstract}
Mass media have significant role on shaping public opinion and image of diplomatic agenda. The control over mass media news enables one to succeed their diplomatic agenda. This paper elaborates the use of mass media in realm of discourse construction, specifically in area of diplomatic. The use of mass media to establish a country's agenda is seen in a case of US intervention to Iraq and Afghanistan. Under Bush's administration, US have succeeded to construct public discourse to gain support for the intervention. By the use of widespread coverage of mass media, the administration delivered a discourse of the intervention role in order to maintain the peace of the world.
\end{abstract}

Keywords: Mass media, diplomacy, and intervention.

\section{PENDAHULUAN}

Diplomasi merupakan agenda rutin sebuah negara untuk menjalin kerja sama dengan negara lain. Sedangkan media massa memiliki peran di dalam membentuk citra atau image sebuah negara di mata negara lain di dalam melakukan agenda diplomasinya. Jadi, diplomasi dan media merupakan sesuatu yang tidak dapat dipisahkan. Hal ini akan berjalan seiring dengan kebutuhan kedua belah pihak untuk saling mendukung kemajuan suatu bangsa. Kemajuan sebuah diplomasi tidak hanya dilihat dari seorang diplomat tetapi didukung melalui sumber-sumber yang mendukung agenda diplomasi malalui peran media massa.

Dari pemaparan di atas, terlihat adanya korelasi yang cukup unik antara media massa dan diplomasi. Oleh karena itu, makalah ini akan mengangkat sebuah studi kasus untuk menggambarkan pola hubungan diantara keduanya. Salah satu studi kasus yang sangat menarik dan kontemporer adalah peran media massa di Amerika Serikat pada era pemerintahan Geore W. Bush dalam kaitannya dengan diplomasi yang ia jalankan. Pada era ini, peran media massa sangat dinamis sehingga jika dikaji lebih mendalam akan diketahui karakter-karakter khusus di dalamnya.

Dinamika media massa pada era Bush merupakan momentum yang menarik. Karena berkaitan dengan berbagai kebijakan luar negeri yang banyak mengundang kritik dan opini publik baik dalam ranah domestik maupun internasional. Berawal dari tragedi 9-11, Presiden Bush kemudian mendapat legitimasi untuk menjalankan politik luar negeri yang ofensif. Misalnya saja dengan menginvasi kedua negara yaitu 
Afganistan dan Irak. Permasalahan yang diangkat oleh media massa di Amerika Serikat seringkali dijadikan instrumen oleh presiden Bush sebagai top decision maker untuk mengkonstruksi wacana publik sesuai dengan apa yang ia inginkan.

Fakta bahwa media massa dapat digunakan Presiden Bush sebagai instrumen pendukung dalam diplomasi. Hal ini dapat dilihat pada era perang dingin, di mana Presiden Bush berhasil menggunakan media massa sebagai instrumen untuk meyakinkan publik mengenai adanya ancaman riil dari Soviet mengenai ideologi komunis. Keberhasilan presiden Bush dalam mengkonstruksi wacana publik tersebut menjadi bagian penting dalam memperlancar kebijakan-kebijakan luar negeri yang diinginkan Presiden. Maka dari itu posisi Presiden pada waktu itu sangat kuat.

Berdasarkan latar belakang tersebut, permasalahan yang kemudian menjadi menarik untuk dikaji lebih mendalam adalah "bagaimana peran media massa dalam diplomasi pada era pemerintahan George W. Bush khususnya dalam kasus invasi AS ke Afganistan dan Irak?

\section{MULTI-TRACK DIPLOMACY DAN AGENDA SETTING THEORY}

Signifikansi media massa dalam ranah diplomasi ini misalnya tercermin dalam konsep multi-track diplomacy. Di dalam konsep ini, sebuah negara memiliki beberapa pilihan track untuk menjalankan diplomasinya. Sedangkan media massa ditempatkan pada $9^{\text {th }}$ track. Hal ini menunjukkan bahwa media massa dapat digunakan suatu negara untuk menjadi instrumen diplomasinya. Demikian juga dalam konsep "the sources of American Foreign Policy as a funel of causality" yang dikemukakan oleh Charles Kagley. Dalam konsep ini media massa ditempatkan sebagai salah satu sumber yang mampu mempengaruhi proses pengambilan kebijakan luar negeri suatu negara khususnya dalam kategori societal sources.

Dalam kaitannya dengan teori-teori dalam studi hubungan internasional tersebut, terdapat agenda setting theory yang sangat relevan untuk menjadi instrumen analisis berita dalam media massa. Teori ini akan membawa analisis yang lebih komprehensif karena mampu menunjukkan dan menjelaskan bagaimana media massa dijadikan instrumen oleh pemerintah untuk mendukung kebijakankebijakannya. Dengan demikian, media massa dapat diasumsikan sebagai instrumen untuk mempengaruhi persepsi publik. Sebagai salah satu teori komunikasi masa, ia melihat bahwa "media shape what to think about not what to think".

Para jurnalis yaitu Professor Maxwell McComb dan Donald Shaw percaya bahwa media massa memiliki kemampuan untuk mentransferkan hal-hal yang penting dari agenda berita mereka ke agenda public. Mereka tidak menyarankan bahwa media siar dan cetak dapat membuat usaha yang disengaja untuk mempengaruhi opini dari pendengar, penonton, atau pembaca dalam pembahasan sebuah isu. McCombs dan Shaw percaya bahwa kita akan berpikir berita itu penting jika media menganggapnya penting. McCombs dan Shaw memaparkan fungsi Agenda Setting dari media massa pada tahun 1972. Ide mereka berasal dari keinginan masyarakat akan pertolongan media dalam penentuan realitas politik. Penelitian lanjutan kemudian dilakukan oleh Bernard Cohen, yang menekankan pada fungsi secara spesifik dari penyajian melalui media. Ia mengatakan bahwa press mungkin tidak sukses setiap saat dalam memberitahukan masyarakat tentang apa yang harus dipikirkan, tetapi dapat dengan sukses dalam membuat 
pemberitahuan kepada audiens akan apa yang harus dipikirkan (not what to think, but what to think about).

Inti dari teori ini adalah media dianggap tidak terlalu berhasil untuk membentuk apa yang harus kita pikirkan, melainkan dapat sukses memberitahukan kepada audiens tentang apa yang harus dipikirkan. Namun, pada perkembangannya tidak sampai di situ saja, namun lebih dari itu, yaitu mempengaruhi cara berpikir kita. Bagaimana carana, ada sebuah metode yang kemudian dapat digunakan dalam pengaplikasian teori ini, yaitu framing. James Tankard mendefinisikan bingkai media (media frame) sebagai sebuah ide utama yang teroganisir dari isi berita yang memberikan isi dan saran tentang sebuah isu melalui seleksi, tekanan, pengeluaran, dan elaborasi. Sehingga hal ini yang membuat media tidak hanya mengatur agenda dari isu, kejadia, atau kandidat siapa yang paling penting, tetapi juga mentransfer atribut spesifik yang penting yang mana tertuju pada objek-objek yang potensial.

Teori ini pada penjelasan yang lebih panjang kemudian tidak hanya menghasilkan opini public saja, tetapi juga berpengaruh terhadap perilaku dari audiens. Sehingga, menurut McCombs dan Shaw fungsi penting dari penyebaranagenda melalui media berpengaruh secara signifikan terhadap cara dari audiens mengidentifikasi diri mereka di dalam kelompok dan pada akhirnya mereka dapat bergabung di dalam kelompok tersebut. Dimulai dengan asumsi bahwa kebanyakan dari kita memiliki kebutuhan yang tinggi akan hubunan. Kita ingin diakui dan cocok dengan yang lain. Melalui kontak interpersonal sehari-hari kita dapat mengetahui jumlah minimal dari masyarakat dan agenda-agenda yang penting menurut mereka. Jika kita kemudian bergabung bersama kelompok tersebut, kita, secara esensi, akan ikut di dalam agenda mereka. Penyebaran-agenda media melihat bahwa media massa memperluas pengetahuan kita tentang pilihan-pilihan yang diberikan oleh media, dan karenanya mereka dapat membantu kita menemukan orang lain yang dapat berbagi dengan kita di dalam media yang sama.

Berdasarkan beberapa landasan teoritis tersebut, maka tulisan ini memiliki argumen bahwa peran media massa pada era pemerintahan George W. Bush mampu mempengaruhi opini publik atas permasalahan-permasalahan yang berkembang. Pengaruh tersebut tidak hanya berhenti pada level domestik saja, namun juga pada level internasional. Hal ini terlihat dari berkembangnya opini publik atas kebijakan luar negeri dan diplomasi Bush dalam kasus invasi AS ke Irak dan Afganistan. Dalam konteks pra invasi dan ketika invasi berlangsung, media massa digunakan pemerintah AS untuk meyakinkan publik domestik dan internasional bahwa apa yang mereka lakukan adalah benar.

\section{MEDIA MASSA SEBAGAI INSTRUMEN DIPLOMASI}

Sebelum membahas secara lebih mendalam tentang peran media massa di AS, sangat penting untuk mengetahui pengertian diplomasi. Pengertian diplomasi cukup beragam. Berikut beberapa pendapat tentang pengertian diplomasi. Pertama, diplomasi dapat dimaknai sebagai alat komunikasi antara dua Negara atau lebih melalui perwakilan untuk mencapai tujuan politik luar negeri. Kedua, diplomasi merupakan seni berkomunikasi dengan cara propaganda untuk mencapai tujuan politik luar negeri. Ketiga, diplomasi dimengerti sebagai komunikasi antara dua 
orang atau lebih dengan melalui perantara (mediator) ataupun tidak di dalam satu negosiasi (perjanjian) untuk mencapai tujuan politik luar negeri.

Unsur-unsur diplomasi dalam diplomasi diantaranya adalah perwakilan, propaganda, negosiasi, mengamati dan melaporkan (observe and report), mendengarkan (listening post), dan mencapai tujuan politik luar negeri. Fungsi diplomasi diantaranya adalah untuk memperbaiki hubungan yang sebelumnya kurang baik/buruk, untuk mencegah perang, untuk mengusahakan terjalinnya kerjasama, untuk membangun opini, untuk melaksanakan politik luar negeri suatu negara.

Multi-Track diplomacy is a conceptual way to view the process ${ }^{1}$. That term refers to a conceptual framework we design to reflect the variety of activities that contribute to international peacemaking and peacebuilding 2 .

Dalam usaha menjaga dan menciptakan perdamaian dunia, dikenal cara-cara yang sangat sangat kompleks, diantaranya adalah melalui diplomasi multijalur. Usaha menjaga perdamaian dunia melalui multitrack diplomacy adalah fokus pada positive peace, yaitu perdamaian jangka panjang yang memiliki dampak positif dalam jangka waktu yang lama (permanen). Dalam level internasional biasanya berupa pembangunan ekonomi yang sinambung, tercapainya keadilan sosial, partisipasi politik, dsb. Dalam positive peace, dipahami bahwa penyebab konflik dan perang adalah kemiskinan dan penjajahan. Sedangkan peacemaking sendiri dapat dimengerti sebagai keseluruhan aktivitas yang terdiri dari peacekeeping, peacebuilding, peace research, peace studies, peace education, dan conflict resolution.

Di dalamnya memuat konsepsi bahwa sebuah negara mampu berhasil dalam sebuah diplomasi bukan hanya ditentukan oleh diplomasi yang dilakukan aktor government saja, akan tetapi juga aktor-aktor di luar pemerintah yang dapat diberdayakan untuk mendukung diplomasi pada level elit tersebut. Dengan kata lain, diplomasi tidak hanya dilakukan hanya oleh lembaga pemerintah tetapi juga oleh semua segmen dalam masyarakat. Untuk itu, departemen luar negeri menggalang kemitraan dengan seluruh komponen masyarakat baik di dalam maupun di luar negeri untuk mensukseskan politik luar negeri.

Louise Diamond dan John Mc Donald mengkategorisasikan tingkatan-tingkatan dalam diplomasi menjadi 9 tingkat/track, yaitu: Track One: Government, Track Two: Nongovernment/Professional, Track Three: Business, Track Four: Private Citizen, Track Five: Research, Training, and Education, Track Six: Activism, Track Seven: Religion, Track Eight: Funding, Track Nine: Communications and Media. Konsep ini sebetulnya senada dengan pengkategorisasian Richard L. Park dalam menganalisis politik luar negeri India dari sudut pandang the policy making process. Ia mengkategorikan aktor yang dapat bermain dalam kebijakan luar negeri sebagai aktor pemerintah (governmental agencies) dan aktor non-pemerintah (non-

\footnotetext{
${ }^{1}$ Atas dasar pengertian bahwa Multi-Track Diplomacy merupakan "way to view" maka tulisan ini mengasumsikan term ini sebagai sebuah "perspektif". Sebetulnya konsep ini muncul pertama-tama untuk melihat proses yang berjalan di Amerika Serikat sebagai " $a$ whole elephant". Namun demikian, dalam perkembangannya perspektif ini dapat digunakan secara universal.

2Louise Diamond dan John McDonald, Multi-Track Diplomacy: A System Approach to Peace, Kumarian Press, hal.1.
} 
governmental agencies) ${ }^{3}$. Perbedaannya adalah Diamond secara lebih detail mengkategorisasikan aktor non-pemerintah kedalam 8 jalur diplomasi.

Jalur yang terakhir, Track Nine: Communications and Media. Yaitu keterlibatan media untuk mengkomunikasikan isu-isu perdamaian, resolusi konflik, dan isu-isu hubungan dan politik internasional. Media yang dimaksud di sini bisa berupa media cetak maupun media elektronik. Posisi media masa dalam kerangka diplomasi digambarkan oleh Diamond seperti Gambar 1.

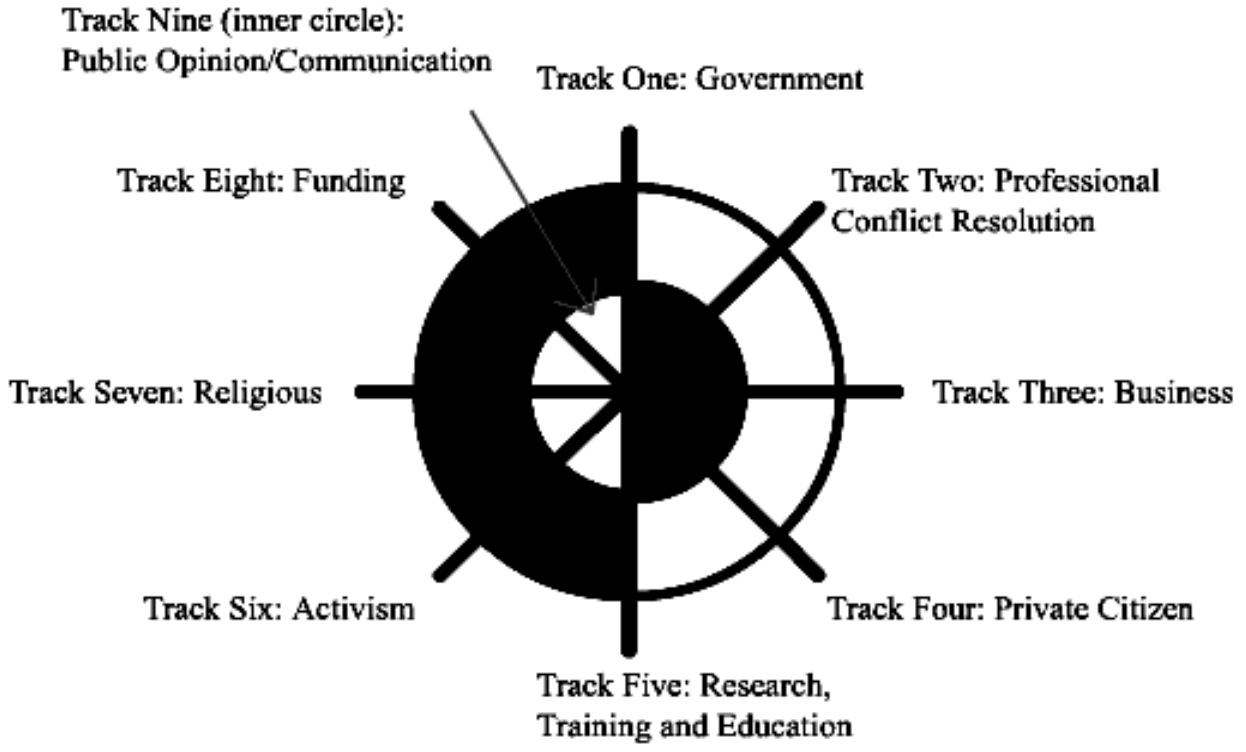

Gambar 1. The Nine Tracks of Multi-Track Diplomacy ${ }^{4}$

Perkembangan dunia media massa pada saat ini memiliki pengaruh dalam kehidupan sosial, politik, ekonomi dan budaya. Media massa ini memberi pengaruh yang cukup signifikan dalam memberikan informasi kepada publik. Hal tersebut dapat dibuktikan oleh adanya kepentingan individu-individu, kelompok-kelompok ataupun pemerintah dalam menyampaikan maksud dan tujuan tertentu. Dukungan media massa dalam hubungan internasional memberikan nuansa baru. Karena media masa mampu memberikan pengaruh serta memberikan sebuah konstruksi sosial terhadap masayarakat. Media massa merupakan sebuah alat yang sangat efektif dalam mempengaruhi pemikiran dan tingkah laku seseorang. Sehingga media massa memiliki fungsi yaitu:

1. Media telah menjadi sumber dominan bukan saja bagi individu untuk memperoleh gambaran dan citra realitas sosial, tetapi juga bagi masyarakat dan

${ }^{3}$ Roy C. Macridis (Ed.), 1958, Foreign Policy in World Politics (Fifth Edition), New Jersey: Prentice-Hall, Inc. hal. 321-325.

${ }^{4}$ Louise Diamond dan John McDonald, Multi-Track Diplomacy: A System Approach to Peace, Kumarian Press, hal. 15. 
kelompok secara kolektif, media menyuguhkan nilai-nilai dan penilaian normatif yang dibaurkan dengan berita dan hiburan

2. Media merupakan sumber kekuatan-alat kontrol, manajemen, dan inovasi dalam masyarakat yang dapat didayagunakan sebagai pengganti kekuatan atau sumber daya lainnya

3. Media merupakan lokasi (atau forum) yang semakin berperan, untuk menampilkan peristiwa kehidupan masyarakat, abik yang bertaraf nasional maupun internasional, media sering kali berperan sebagai wahana pengembangan bentuk seni dan simbol tetapi juga dalam pegertian pengembangan tata-cara, mode, gaya hidup dan norma-norma. ${ }^{5}$

Hal ini berkaitan erat dengan suatu negara dalam menyampaikan misi diplomasinya. Diplomasi yang dilakukan oleh suatu negara dalam menyampaikan misi atau agenda yang dijalankan untuk mendukung kepentingannya. Sehingga diplomasi menjadi suatu tindakan yang memiliki peran penting dalam menjalankan tugas bagi seseorang Presiden, Menteri Luar Negeri atau Perdana Menteri di dalam mencapai tujuan dari politik luar negerinya. Disamping itu diplomasi menjadi pusat dari segala keberhasilan suatu hubungan antar bangsa.oleh karena itu Politik luar negeri suatu Negara merupakan suatu hal yang tidak dapat dipisahkan. Karena poilitik luar negeri merupakan inti (substansi) dari politik dalam negeri dan diplomasi merupakan suatu cara atau metode untuk mencapai tujuan dari kepentingan nasional.

Diplomasi yang dijalankan oleh suatu negara dalam mencapai tujuan yang akan dicapai. Hal ini tidak terlepas oleh peran dari media massa. Karena saluran-saluran yang djalankan oleh media massa sangat efektif dalam mempengaruhi suatu penilaian seseorang terhadap suatu masalah atau kasus yang sedang terjadi. Karena dunia sosial, termasuk dalam hubungan internasional, merupakan konstruksi sosial. Sehingga dunia sosial merupakan wilayah intersubjektif; dunia sosial sangat berarti bagi masyarakat yang membuatnya dan hidup di dalamnya. ${ }^{6}$ kondisi ini merupakan kekuatan-kekuatan dari media massa sebagai alat dari diplomasi. Diplomasi merupakan suatu agenda penting yang dijalankan oleh suatu pemerintahan untuk menyampaikan maksud dan tujuan negaranya baik kepada masyarakat dalam negerinya atapun masyarakat internasional. Oleh karena itu, media massa memberikan pengaruh yang cukup efektif dalam memberikan opini kepada masyarakat. Sehingga kondisi ini akan mempermudah peran dari suatu pemerintah untuk melakukan hubungan diplomatiknya dengan negara manapun. Karena pada era globalisasi dan modernisasi memberikan kenudahan-kemudahan bagi seluruh aspek dalam kehidupan, salah satunya dalam mendukung diplomasi suatu negara.

Oleh karena itu, tujuan diplomasi dari masa lalu sampai dengan sekarang memiliki tujuan yang atau efektif adalah untuk menjamin keuntungan maksimum negara sendiri. Sehingga salah satu kesuksesan suatu diplomasi suatu negara terletak pada tercapainya kepentingan dari negara bangsa tersebut. Dengan demikian diplomasi merupakan unsur yang penting didalam mencapai tujuan

\footnotetext{
${ }^{5}$ McQuail, Denis, Teori Komunikasi Massa, Erlangga, Jakarta, 1989, hal. 3.

${ }^{6}$ Robert Jackson \& Georg Sorensen, Pengantar Studi Internasional, Pustaka Pelajar, 2005, Yogyakarta,hal. 307.
} 
nasional dari suatu negara bangsa. Sehingga suatu negara bangsa sangat menjaga hubungan diplomatiknya yang telah terbangun dengan beberapa negara-negara yang ada didunia dengan didukung oleh peran media massa. Dengan hal itu, maksud dan tujuan dari sebuah negara mampu memberikan gambaran kepada masyarakat luas. Hal ini merupakan alat yang paling efektif yang dilakukan oleh suatu negara untuk mengubah sebuah citra suatu negara dalam agenda setting suatu negara dalam menjalankan misi diplomatiknya.

\section{MEDIA MASSA DAN DIPLOMASI AMERIKA SERIKAT}

Perspektif lain juga melihat media massa sebagai instrumen penting dalam ragam diplomasi yang spesifik, yaitu diplomasi publik. Dalam salah satu definisi yang dikemukakan oleh Gullion, diplomasi publik diartikan sebagai upaya mencapai kepentingan nasional suatu negara melalui understanding, informing, and influencing foreign audiences ${ }^{7}$. Pendekatan ini sangat berbeda dengan diplomasi tradisional yang dikembangkan melalui mekanisme government to government relations. Diplomasi publik lebih menekankan pada government to people atau bahkan people to people relations. Tujuannya adalah agar masyarakat internasional mempunyai persepsi baik tentang suatu negara, sebagai landasan sosial bagi hubungan dan pencapaian kepentingan yang lebih luas. Lebih dari itu, munculnya konsepsi diplomasi publikpun berkorelasi kuat dengan politik luar negeri Amerika Serikat. Berikut kutipan yang menegaskan tentang korelasi tersebut: "Public diplomacy refers to government-sponsored programs intended to inform or influence public opinion in other countries; its chief instruments are publications, motion pictures, cultural exchanges, radio and television."

Dengan demikian, media massa (yang identik dengan publikasi massa, radio, dan televisi) merupakan instrumen strategis untuk membentuk opini, baik domestik maupun global. Perkembangan informasi dan telekomunikasi telah menggeser pandangan tradisional tentang "membentuk citra baik". Pemerintahan di dunia tidak dapat lagi berpropaganda untuk memanipulasi realitas. Citra dan realitas tidak dapat lagi dipisahkan, dimana untuk memperbaiki citra, maka realitas yang terlebih dahulu diperbaiki. Media massa akan menjadi komunikator yang mentransformasinya menjadi citra.

Untuk melihat peran media massa sebagai instrumen diplomasi AS secara lebih mendalam, berikut ini akan dipaparkan analisis sample berita tentang invasi AS ke Irak dan Afganistan. Tentu saja berita yang dipilih merupakan berita yang dipublikasikan melalui media-media utama AS yang memiliki jangkauan pemasaran luas di dunia.

\section{Berita tentang invasi ke Afganistan}

Di dalam memberitakan tentang Afghanistan, media massa Amerika cenderung menggunakan salah satu kelompok garis keras yang dianggap sebagai teroris oleh

\footnotetext{
${ }^{7}$ USIA Alumni Association, 2008, Public Diplomacy, http://www.publicdiplomacy.org/1.htm, diakses pada 20 September 2008.

8 U.S. Department of State, 1987, Dictionary of International Relations Terms, hal. 85.
} 
Amerika, Taliban. Kelompok ini dianggap merupakan kelompok Islam garis keras yang dianggap sebagai kelompok yang melakukan terorisme pada tanggal 11 September 2001 lampau. Isi artikel tersebut terkesan memberitakan bahwa Amerika hanya menyerang kelompok Taliban saja, bukan menyerang Afghanistan, yang dinyatakan sebagai basis dari kelompok ini. Berikut penggalan artikel yang diambil dari washingtonpost yang dipublikasikan dalam versi cetak pada tanggal 29 April 2008.

\section{U.N.'s Envoy To Afghanistan Sees Threats To Progress}

A fragmented international effort and weak government in Kabul have combined to endanger everything that has been accomplished in Afghanistan since the ouster of the Taliban nearly seven years ago, the new U.N. envoy to Afghanistan said yesterday. Norwegian diplomat Kai Eide said he sees "some hopeful signs" after his first visit to Afghanistan and talks with European and U.S. leaders. But he said the overall effort remains "under-resourced" and uncoordinated.

"I think there is a growing recognition that it is urgent," Eide said. "We all see that if we don't bring a basis of good government and rule of law" to Afghanistan, progress on the military and development front will be unsustainable, he said.

The post Eide took over last month had been vacant since the end of last year. Afghan President Hamid Karzai rejected Paddy Ashdown -- the British politician initially selected for the job of coordinating among international military and civilian activities and the Afghan government -- on the grounds that he would exercise too much influence over Kabul's decision-making.

In an interview, and in a speech here yesterday at the Carnegie Endowment for International Peace, Eide emphasized the need to let Afghans make their own decisions.

"I profoundly believe that it is their country and they know it better than we ever will," he said.

While there has been progress in health and education services, he said, police training, government capacity-building and agriculture still need more resources. Efforts by individual donors duplicate each other or overlap, and too many aid projects are tied to purchases and decision-making in the West. U.S. and NATO forces have scored tactical victories against a resurgent Taliban but have failed to prevent the Pakistan-based extremists from expanding their hold over rural areas.

Despite its long skepticism of U.N. involvement in both Iraq and Afghanistan, the Bush administration has become eager in recent years to increase the international profile in both countries. Eide's Washington visit has been given high priority, including a daytime meeting and dinner with Secretary of State Condoleezza Rice yesterday and a White House visit with President Bush today. "It is a tough job," Rice said of Eide's mission. "We understand that."

Di dalam artikel ini, Afghanistan digambarkan sebagai Negara yang tidak memiliki aturan dan hukum yang dapat mengatur warga Negaranya. Terlihat dari paragraph yang mengutip kalimat dari Kai Eide, seorang diplomat dari Norwegia. Kalimat tersebut jelas sekali menyatakan bahwa Afghanistan adalah Negara yang tidak memiliki aturan di dalam pemerintahannya, dan tugas Negara-Negara lainnya 
untuk memberikan bentuk Negara yang "beradab" seharusnya. Dengan campur tangan Negara lain, maka mereka dapat memberikan bentuk pemerintahan, hukum yang sebenarnya dimiliki oleh sebuah Negara. Karena di Negara Afghanistan sendiri juga terdapat kelompok militer yang dianggap sebagai teroris bagi Negara-Negara Barat, terutama Amerika, karena Taliban, sebagai kelompok militer yang ada di Afghanistan, dan sebagai kelompok yang disangka sebagai kelompok yang melakukan terorisme di Amerika, dengan tragedy WTC tanggal 11 September silam.

Di dalam artikel ini, dijelaskan penyerangan Amerika ke Afghanistan bukanlah untuk menyerang Afghanistannya, melainkan memerangi terorisme ataupun bentukbentuk pemerintahan yang tidak sesuai dengan prinsip demokrasi, harus diubah. Dengan menggunakan kekuatan militer, bentuk pemerintahan seperti itu akan semakin cepat digantikan dengan pemerintahan yang "seharusnya". Apalagi di dalam artikel diatas, diberitakan tentang ketidakmampuan pemerintah Afghanistan untuk mengatur Negaranya, dengan korupsi dikalangan pemerintahan, dan peredaran obat terlarang yang semakin sulit untuk di berantas oleh pemerintahan Taliban itu sendiri.

\section{Berita tentang invasi ke Iraq}

Berikut ini adalah analisis media yang akan digunakan untuk melihat bagaimana media dapat membentuk opini publik terhadap pemberitaan akan perang yang terjadi di Irak. Media massa yang digunakan adalah TIME, sebuah media massa online. Media massa ini adalah media massa yang juga memuat artikel yang sama pada tanggal 23 Mei 2007 di versi media cetaknya. Berikut ini adalah penggalan artikel yang berjudul "Is Al-Qaeda on the Run in Iraq?" beserta analisis framingnya.

\begin{tabular}{|c|c|}
\hline Isi Berita & Framing \\
\hline $\begin{array}{l}\text { There is good news from Iraq, believe it or } \\
\text { not. It comes from the most unlikely place: } \\
\text { Anbar province, home of the Sunni insur- } \\
\text { gency. The level of violence has plummeted in } \\
\text { recent weeks. An alliance of U.S. troops and } \\
\text { local tribes has been very effective in moving } \\
\text { against the al-Qaeda foreign fighters. A } \\
\text { senior U.S. military official told me-con- } \\
\text { firming reports from several other sources- } \\
\text { that there have been "a couple of days recently } \\
\text { during which there were zero effective attacks } \\
\text { and less than } 10 \text { attacks overall in the } \\
\text { province (keep in mind that an attack can be } \\
\text { as little as one round fired). This is a result of } \\
\text { sheiks stepping up and opposing AQI [al- } \\
\text { Qaeda in Iraq] and volunteering their young } \\
\text { men to serve in the police and army units } \\
\text { there." The success in Anbar has led sheiks in } \\
\text { at least two other Sunni-dominated } \\
\text { provinces, Nineveh and Salahaddin, to ask }\end{array}$ & $\begin{array}{l}\text { Bahwa di Timur tengah sendiri, } \\
\text { segala macam bentuk penyerangan } \\
\text { yang dilakukan Al-Qaeda adalah } \\
\text { sebuah kegiatan terorisme. Bahkan } \\
\text { di dalam wilayah yang merupakan } \\
\text { tempat asal suku Sunni, yaitu suku } \\
\text { yang banyak ada di kelompok Al- } \\
\text { Qaeda. } \\
\text { Pemahaman bentuk terorisme ada- } \\
\text { lah segala macam yang dilakukan } \\
\text { oleh Al-Qaeda, yang mengancam } \\
\text { jiwa seluruh masyarakat di Timur } \\
\text { tengah. Merupakan hal yang di } \\
\text { generalisir. Dengan diberitakannya } \\
\text { dukungan suku Sunni akan pem- } \\
\text { berantasan Al-Qaeda di timur } \\
\text { tengah oleh Amerika, memberikan } \\
\text { arti bahwa Amerika adalah Negara } \\
\text { yang tepat untuk memberantas } \\
\text { bentuk terorisme tersebut. }\end{array}$ \\
\hline
\end{tabular}




\begin{tabular}{|c|c|}
\hline Isi Berita & Framing \\
\hline $\begin{array}{l}\text { for similar alliances against the foreign } \\
\text { fighters. And, as TIME's Bobby Ghosh has } \\
\text { reported, an influential leader of the Sunni } \\
\text { insurgency, Harith al-Dari, has turned } \\
\text { against al-Qaeda as well. It is possible that } \\
\text { al-Qaeda is being rejected like a mismatched } \\
\text { liver transplant by the body of the Iraqi } \\
\text { insurgency. } \\
\text { The good news comes with caveats, of course. } \\
\text { The removal of AQI's havens in Anbar may } \\
\text { ultimately hurt the terrorists' ability to blow } \\
\text { up markets in Baghdad, but it hasn't yet. As } \\
\text { Ireported in September } 2005 \text {, there is also the } \\
\text { scandalous reality that an alliance with the } \\
\text { tribes was proposed by U.S. Army intelligence } \\
\text { officers as early as October 2003 and rejected } \\
\text { by L. Paul Bremer's Coalition Provisional } \\
\text { Authority on the grounds that "tribes are part } \\
\text { of the past. They have no place in the new } \\
\text { democratic Iraq." The damage caused by that } \\
\text { myopic stupidity may never be repaired: it } \\
\text { gave al-Qaeda a base in the Sunni tribal } \\
\text { areas, which enabled the sustained, } \\
\text { spectacular anti-Shi'ite bombing campaign, } \\
\text { which, along with the Sunnis' historic } \\
\text { disdain for the Shi'ite majority, created the } \\
\text { conditions for the current civil war. "Just } \\
\text { because the Sunni tribesmen have joined } \\
\text { with us in Anbar doesn't mean they like the } \\
\text { Baghdad government," a senior } \\
\text { Administration official told me. "They just } \\
\text { hate al-Qaeda more." }\end{array}$ & $\begin{array}{l}\text { Pemberitaan di paragraph ini yang } \\
\text { menunjukkan bahkan suku Sunni } \\
\text { sendiri merasa tidak menyukai } \\
\text { kelompok Al-Qaeda ini, maka } \\
\text { dengan begitu, akan sangat mudah } \\
\text { untuk Amerika dan tentaranya } \\
\text { menyerang Irak. }\end{array}$ \\
\hline
\end{tabular}

Begitu pula dengan isi paragraf-paragraf selanjutnya, dimana isi berita tersebut selalu ingin meyakinkan publik bahwa apa yang dilakukan Amerika adalah benar. Misalnya saja dengan terus-menerus menekankan bahwa Amerika adalah negara yang diberikan kewenangan untuk memberantas terorisme, dan dengan menyebutkan tragedy 9/11 adalah sebuah bentuk terorisme, dengan dalangnya adalah orang yang berasal dari timur tengah, maka pembentukan opini masyarakat akan terorisme dan timur tengah akan menemukan titik temu. Dan hal ini yang kemudian memberikan pemahaman akan opini publik masyarakat yang mengarah ke dukungan masyarakat akan perang yang terjadi di Irak.

\section{KESIMPULAN}


Hubungan diplomasi dengan media massa merupakan dua hal yang tidak dapat dipisahkan. Karena kedua hal tersebut memberikan kekuatan yang luar biasa dalam mempengaruhi opini publik. Melihat kondisi sosial, ekonomi dan politik di dalam negeri maupun luar negeri. Hal ini tidak terlepas oleh informasi-informasi yang disampaikan oleh media massa. Disisi lain, diplomasi merupakan instrument bagi suatu negara untuk menyampaikan misi diplomatiknya yang ditujukan ke dalam negeri maupun ke luar negeri. Oleh karena itu, ukuran dari keberhasilan suatu negara dalam menyampaikan misinya dapat dilihat dari sisi diplomasi yang dijalankan oleh aktor-aktor state atau media massa sebagai mediasi dalam menyampaikan kepada publik. Melalui media massa, keinginan dari Amerika Serikat untuk membentuk opini publik sesuai dengan keinginan AS tersebut akan sangat mudah. Media massa akan memberikan informasi yang diinginkan oleh AS tersebut kepada masyarakatnya. Karena dengan melalui media massa, akan sangat mudah untuk membentuk opini publik, bahkan hingga kepada perilaku publik terhadap suatu pemberitaan, tergantung dari bagaimana berita itu disampaikan. Penyampaian berita kemudian tergantung kepada keinginan pemerintah untuk membentuk opini publik. Karena itu, diplomasi melalui media massa biasanya dilakukan untuk membentuk opini masyarakat secara luas.

Dari beberapa contoh berita yang telah dianalisis memang terbukti bahwa pemerintah AS di bawah George Walker Bush Jr. berusaha untuk meraih dukungan publik dengan instrumen media massa. Pertama, pemerintah Bush berusaha mengkonstruksi wacana publik internasional bahwa "terorisme" (dalam kasus Afganistan) dan "senjata pemusnah massal" (dalam kasus Irak) merupakan merupakan ancaman nyata bagi rakyat AS dan seluruh masyarakat dunia. Media massa-lah yang paling berperan dalam proses konstruksi ini sehingga hampir semua orang di dunia merasakan bahwa terorisme merupakan ancaman nyata. Kedua, terbentuknya persepsi ini pada akhirnya diharapkan dapat memperkuat dukungan dunia terhadap AS untuk melakukan invasi ke Afganistan dan Irak. Ketiga, dalam proses invasi media massa tetap memiliki peran sentral untuk menunjukkan pembenaran dan kesuksesan invasi AS dalam kerangka pencapaian perdamaian dunia. Analisis tersebut dilihat dari perspektif pemerintah AS yang selalu ingin "menyetir" media massa. Dengan demikian kesemuanya terlepas dari perspektif media massa sebagai sebuah lembaga independen.

\section{DAFTARPUSTAKA}

De Tocqueville, Alexis, 1945, Democracy In America, New York: Vintage Book.

Griffin, EM. 2003. A First Look at Communication Theory. US. McGraw-Hill Comanies, Inc.

Ippolito, Dennis S. dan Thomas G. Walker, 1980, Political Parties, Interest Groups, and Public Policy: Group Influence In American Politics, New Jersey: PrenticeHall Inc.

Kegley, Charles W, 1996, American Foreign Policy $5^{\text {th }}$ ed., New York: St. Martin's Press.

Littlejohn, Stephen W. 2004. Theories of Human Communication $8^{\text {th }}$ ed. California. Wadsworth Publishing Company. 
Louise Diamond dan John McDonald, 1991, Multi-Track Diplomacy: A System Approach to Peace, Kumarin Press.

Mulyana, Dedi. 2003. Ilmu Komunikasi Suatu Pengantar. Bandung. PT Remaja Rosdakarya.

Roy C. Macridis (Ed.), 1976, Foreign Policy in World Politics (Fifth Edition), New Jersey: Prentice-Hall, Inc.

Wilson, James Q, 2003, American Government $6^{\text {th }}$ ed. (Brief Version), Boston: Houghton Mifflin Company. 